\title{
Switching 300 MW Power-Generating Units with Gas-and-Oil-Fired Boilers to Increased Load Mode
}

\author{
Stepan Mysak, Marta Kuznetsova*, Marta Martynyak-Andrushko \\ Lviv Polytechnic National University, 12, Stepan Bandera Str., Lviv, 79013, Ukraine
}

Received: March 22, 2021. Revised: April 12, 2021. Accepted: April 19, 2021.

(C) 2021 The Authors. Published by Lviv Polytechnic National University.

\begin{abstract}
The goal of the research is to develop the guidelines for increasing the capacity of the operating $300 \mathrm{MW}$ powergenerating units by using the allowances assumed at the design computations and manufacture of the powergenerating equipment, while preserving its reliability criteria and performance efficiency. The capacity of the operating power-generating units is increased in three stages. During the first stage, the technical state and operation conditions are established, measures aimed at increasing the capacity and increased load capabilities and reasons that may restrict them, as well as modernization and reconditioning measures are determined. The second stage includes developing technical solutions and reconstruction measures to increase the transfer capacity of the systems. At the third stage, the study and testing of the power-generating units' equipment in the wide load range, including overload modes, are carried out with assessing and comparing the reliability criteria and efficiency indices. Technical measures intended to upgrade and modernize the equipment are low-cost. Most of them consist in ensuring the normal operating state of the existing main and auxiliary equipment of the power generating units.
\end{abstract}

Keywords: power-generating unit; boiler; increased load; modernization; reconstruction.

\section{Substantiation of the research theme}

Year by year, electricity consumption is growing rapidly both in Ukraine and globally, which stems from the economic growth, increasing investments in Ukraine, and, respectively, from launching new production capacities. This factor is behind the continually growing load on the Ukrainian power grid, and first and foremost on TPPs, which provide for the manoeuvrability of the power grid. Given the present deficit of manoeuvrable and powergenerating capacities and a scanty number of new power-generating units being built at TPPs, raising the capacity of the already operating power-generating units and increasing electrical power production due to implementing relatively low-cost measures are tasks of topical importance.

The operation of the TPP main and auxiliary technological equipment has a decisive influence on the reliability and efficiency of the whole power plant. Besides, the normal functioning of power-generating equipment is important for other industries, as a stable operation of both individual mechanisms and whole plants relies on uninterrupted power supply, and hence on trouble-free performance of such equipment [1]. The maximally efficient use of the equipment available at TPP makes it possible to avoid significant costs on putting into operation new power capacities. Along with that, this allows raising the efficiency of using the existing equipment. Measures aimed at improving the performance of the available machinery are promising not only from the economic and technological perspectives [2]-[4]. Another key issue to be tackled during such works is environmental problems [5], [6].

\footnotetext{
*Corresponding author. Email address: marta.y.kuznetsova@1pnu.ua
}

This paper should be cited as: S. Mysak, M. Kuznetsova, M. Martynyak-Andrushko. Switching 300 MW powergenerating units with gas-and-oil-fired boilers to increased load mode. Energy Engineering and Control Systems, 2021, Vol. 7, No. 1, pp. 32 - 37. https://doi.org/10.23939/jeecs2021.01.032 
The efficiency of thermal power plants can be increased using various methods. It is proposed that the performance and maneuverability characteristics of TPP can be improved by condensate throttling [7], integrating high temperature thermal energy storage into the TPP heat balance diagram through an additional thermodynamic cycle [8], introducing new air preheating systems [9] and developing simulation models that precisely predict TPP behaviour at various loads [10].

Therefore, operation of the available equipment using new organizational and technological solutions is a real way of enhancing technical and economic parameters of power plants and extension of their service life at costs that are significantly lower than the costs needed to put into operation new advanced power generating capacities.

\section{Research goal}

The research aims to determine necessary organizational and technological measures designed to ensure a 10$12 \%$ increase in the capacity of the operating $300 \mathrm{MW}$ power-generating units with TGMP-314 TKZ gas-and-oilfired boilers and to study the TGMP-314 boiler operation in increased load modes. The capacity is to be raised by employing the allowances assumed at the design computations and manufacture of the power-generating equipment. Such reserves provide for an increased load and design operation parameters while preserving the reliability criteria and efficiency indices allowed for by the equipment manufacturers.

\section{Development of technical measures for running the equipment in the increased load mode}

To design an effective strategy for raising the capacity of the operating power-generating units, it is necessary to use measures of enhancing and modernization of the existing equipment that are as low-cost as possible. These measures are to include technical solutions aimed at increasing the efficiency of the main assembly units of the boiler and all the auxiliary equipment, as well as testing of the boiler operation in increased load modes.

The capacity of the operating power-generating units is increased in many stages, the key ones being the inspection of the technical state and operating conditions of the main and auxiliary equipment available at TPP with further deciding on and devising of a strategy for enhancement and modernization of this equipment. The implemented organizational measures must clearly draw up the requirements for reconditioning and modernization of the main and auxiliary equipment and at the final stage provide for the testing of the power-generating unit at an increased load with assessment of the reliability, environmental and efficiency parameters.

When performing the inspection, the major focus should be on testing and studying the operation modes of the equipment in order to determine its increased load capabilities and factors that can restrict increasing the capacity above the nominal value. Such studies should include installing possible reserves of increasing the load in terms of fuel feed, air feed, draft, paths resistance, a sufficient range of measuring devices, etc. No less important is mapping out technical measures supposed to ensure reliable operation of the equipment at an increased load. The inspection is also important for obtaining initial data for computations and establishing the reliability, environmental and efficiency parameters of the equipment operation in the modes other than nominal ones.

A specific focus should be made on a detailed visual inspection of all the assembly units and mechanisms of the boiler to evaluate their design (during the reconditioning) in order to find out the reasons for the limited capacity and to finalize the scope of technical measures aimed at their elimination. Particular attention is confined to the elements and mechanisms of the boiler having the most profound effect on the capacity increase and reliability of the operation in increased load modes. Such inspection is required taking into account the long-term operation of the equipment and a large number of scheduled and emergency repairs, the quality of which has a direct effect on the technical state of the equipment.

To reduce costs on services making it possible to run the equipment at an increased load, it is important to use the available standard systems and measuring devices. Such systems and control room instrumentation are subject to mandatory preliminary checks and are used, in particular, for controlling thermal flows heightwise of the furnace, nitrogen oxides levels in the combustion gas, temperature of the convective superheater platen metal and pipes of the lower radiant part in the spots of the highest metal stress at the level of upper burners. Essentially, the requirements to the technical state of the equipment operating at the nominal load and at an increased load are the same. The mandatory requirement is to ensure the reliable and efficient operation of the equipment. The boiler furnace must meet the technical regulations regarding wall insulation density, especially in the places of connecting the burner devices to the furnace walls and in places where the wall tubes go through the brickwork, fastening of the hatches, 
manholes, sensors of the instruments, etc. Burner devices as the main element of the boiler must ensure complete combustion of the fuel, without incomplete combustion, with permissible levels of controlled emissions. Additional organizational requirements to be fulfilled for a reliable operation of the power-generating units at increased loads is mandatory organization of gas or fuel oil combustion modes with extremely low air access $(1.015-1.025$ for fuel oil and $1.030-1.050$ for gas).

Therefore, inspection of the technical state and operating conditions of TPP with TGMP-314 gas-and-oil-fired boilers allows revealing the factors restricting its efficiency. Analysis of the information obtained during the inspection of the main and auxiliary equipment revealed the main factors determining the load value at which TPP equipment can function safely. They are limit values of the steam pressure in the resuperheating system and in the turbine control stage and of the superheated steam pressure in the final boiler outlet headers, limited efficiency of the induced-draft fans and forced-flow fans, fuel oil or gas burners, as well as limited steaming through the turbine wheelspace and limit temperature of the tube metal of specific heating surfaces.

Attention should be paid to regenerative air heaters (RAH) as important elements of the boiler that most significantly influence not only its efficiency, but substantially determine the reliability of the unit and its limit capabilities with respect to the steam capacitance. It was established that the factors having the strongest effect on the RAH efficiency are sealing design, air leakage and infiltration rates and pollution intensity. This considered, one can formulate major requirements complying with which will ensure RAH operation in increased load modes. In case of the replacement of metal sheet packs in the course of repairs, the design heat exchange area of RAH should be ensured. The thickness of the sheets, sheet profile, height of the sheets in packs and sheets packing density must meet the technical regulations, reliable functioning of all the types and sealing systems must be ensured and an efficient system of cleaning the metal sheet packs from ash buildup must be used. Fulfilment of these requirements is vital for a reliable and efficient RAH operation. For instance, high-performance regulation of the sealing systems alone suffices to ensure minimum air leakage and infiltration at the level of $17-18 \%$. The study of the effect of the RAH heat exchange area for RPP-98 regenerative air heaters installed in TGMP-314 boilers by mode calculations method for heat transfer systems shows that a $10 \%$ reduction in the heat exchange area results in a $6.7 \%$ increase in the exhaust gas temperature and in a $7.2 \%$ drop in the hot air temperature.

In case of induced draft fans, the allowance made in the aerodynamic calculations is another reserve that can be used for the operation in an increased load mode. This reserve can amount to $10-12 \%$ of the head and $5-7 \%$ of the efficiency. The use of the reserve is possible due to quality implementation of the machine's working part with mandatory keeping of the recommended gap clearance between the casings and rotating blades at 6-8 $\mathrm{mm}$, while the actual values when operating the induced draft fans are $8-40 \mathrm{~mm}$ and more. The use of a reliable design of sealing in places where the shafts go through the casing is another factor making the use of the reserve possible. The purely organizational measures allowing the operation at increased loads include a reliable and tried-out method of shifting the electric motors of the forced-flow fans from the first to the second gear, while providing for a synchronous opening of the segments of the guide vanes. Thereat, as in case of induced draft fans, care should be taken to reduce the recommended clearance gaps between the fan wheel and casing down to 5-7 $\mathrm{mm}$ for their actual value of 10$30 \mathrm{~mm}$.

An important condition of possible operation of the boiler at increased loads is ensuring the standard-compliant tightness of the convection shaft and gas ducts. The total unorganized air infiltration in the zone economizer- induceddraft fan must not exceed $24-25 \%$. The analysis of the boilers operation revealed that typically the most permeable places are those where the wall tubes go through the brickwork, connections of the gas ducts, gas compensator before and past RAH, etc. Even a 2-3\% reduction in unorganized air infiltration into the gas ducts can be used as a significant reserve for providing the boiler with the required draft at increased loads.

Therefore, to ensure constant readiness of power-generating units to work at increased loads, it is necessary to provide a high level of operation and maintenance of the main and auxiliary equipment, and control systems. Thus, as mentioned above, an important factor of reliable operation of power-generating units in increased load modes is timely quality reconditioning works during routine, midlife repairs and major overhaul.

The obtained results of technical state inspection and testing of the equipment are used for determining the scope and volume of technical measures aimed at preparation of the boilerhouse equipment for increased load operation modes. Most of such measures are low-cost and mainly consist in fulfilling the conditions of the technical state and requirements set out by the manufacturer when supplying the equipment. Besides, additional measures can be 
proposed, which are aimed at ensuring design and calculated reliability indices, as well as mode and economic parameters of operation at increased loads. They can include the removal of the bottom wall insulation in order to reduce the heat liberation rate per unit area and tube metal temperature in the zone of maximum heat liberation and increase the heat absorption rate of the lower radiant part, the bottom wall being its component. The verification analysis of the fuel-oil-fired boiler furnace shows that the removal of the bottom wall insulation ensures raising the thermal efficiency factor of the bottom wall from 0.10 to 0.55 , and in general for the heating surfaces from 0.482 to 0.523. The gas temperature in the zone of maximum heat liberation of the lower radiant part is reduced by $48^{\circ} \mathrm{C}$ and the heat flow by approximately $50000 \mathrm{kcal} / \mathrm{m}^{2} \cdot \mathrm{h}$.

The final mandatory stage of switching the power-generating units into increased load modes is studying the equipment operation at these loads. The technique of such study includes obtaining the main mode parameters of the main and auxiliary equipment at gradual, incremental increase of the power-generating unit load from 300 to 330 $340 \mathrm{MW}$. To do this, the capacity of the power-generating unit is increased in increments of 5-10 MW with further mandatory maintaining the load for 50-60 min. at every step. While the equipment is operating at an intermediate increased load, the temperature, pressure, displacement and flow rates are measured using standard instruments. The obtained data is used for estimating the reliability and efficiency criteria of the power-generating unit performance. To assess the mode, economic and environmental indices and criteria of the power-generating unit reliability, the testing was carried out based on the three following fixed load values: nominal load of $300 \mathrm{MW}$, intermediate load of 315-320 MW and maximum load of 330-340 MW. The test duration was at least $60 \mathrm{~min}$. for the first load value and $120 \mathrm{~min}$. for the third load value, without taking into account the time required for a mode stabilization (20-30 min.).

\section{An example of the equipment operation at an increased load}

The studies were carried out on the TGMP-314 natural gas fired boiler. The load of the power-generating unit was changed in the range from 300 to $330 \mathrm{MW}$ with a $10 \mathrm{MW}$ increment. The results for the TGMP-314 boiler at increased loads are presented in Table 1.

Table 1. Mode parameters of TGMP-314 natural gas fired boiler operation

\begin{tabular}{|c|c|c|c|c|}
\hline \multirow{2}{*}{ Parameter } & \multicolumn{4}{|c|}{ Load, MW } \\
\hline & 300 & 310 & 320 & 330 \\
\hline Feed water flow rate, $t / h$ & 990 & 1030 & 1050 & 1070 \\
\hline Feed water pressure, $\mathrm{kgf} / \mathrm{cm}^{2}$ & 275 & 278 & 280 & 285 \\
\hline Feed water temperature, ${ }^{\circ} \mathrm{C}$ & 260 & 262 & 264 & 265 \\
\hline Ambient temperature upstream of the in-built valve, ${ }^{\circ} \mathrm{C}$ & 400 & 400 & 400 & 400 \\
\hline Superheated steam flow rate, $\mathrm{t} / \mathrm{h}$ & 980 & 990 & 1030 & 1050 \\
\hline Superheated steam pressure, $\mathrm{kgf} / \mathrm{cm}^{2}$ & 240 & 243 & 245 & 247 \\
\hline Superheated steam temperature, ${ }^{\circ} \mathrm{C}$ & 545 & 545 & 545 & 545 \\
\hline Steam temperature upstream of the $2^{\text {nd }}$ injection, ${ }^{\circ} \mathrm{C}$ & 475 & 477 & 480 & 485 \\
\hline Reheat steam pressure, $\mathrm{kgf} / \mathrm{cm}^{2}$ & 34 & 35 & 36 & 37 \\
\hline Reheat steam temperature, ${ }^{\circ} \mathrm{C}$ & 545 & 545 & 545 & 545 \\
\hline Gas flow rate, $\times 1000 \mathrm{~m}^{3} / \mathrm{h}$ & 79 & 83 & 87 & 91 \\
\hline Gas pressure downstream of the regulating valve, $\mathrm{kgf} / \mathrm{cm}^{2}$ & 1.70 & 1.73 & 1.76 & 1.80 \\
\hline Hot air temperature, ${ }^{\circ} \mathrm{C}$ & 320 & 323 & 325 & 330 \\
\hline Air pressure downstream of the forced-draught fan, $\mathrm{kgf} / \mathrm{cm}^{2}$ & 340 & 360 & 380 & 400 \\
\hline $\mathrm{RAH}$ resistance, $\mathrm{kgf} / \mathrm{cm}^{2}$ & 60 & 65 & 72 & 80 \\
\hline Gas pressure in the upper part of the furnace, $\mathrm{kgf} / \mathrm{cm}^{2}$ & \multicolumn{4}{|c|}{$2-3$} \\
\hline Gas temperature, ${ }^{\circ} \mathrm{C}$ & 760 & 780 & 800 & 830 \\
\hline Exhaust gas temperature, ${ }^{\circ} \mathrm{C}$ & 144 & 146 & 148 & 150 \\
\hline Oxygen level downstream of the convective superheater, $\%$ & \multicolumn{2}{|c|}{$0.7-0.6$} & \multicolumn{2}{|c|}{$0.6-0.5$} \\
\hline NOx level past the convective superheater, $\mathrm{mg} / \mathrm{m}^{3}$ & 220 & 240 & 280 & 330 \\
\hline RAH air duct resistance, $\mathrm{kgf} / \mathrm{m}^{2}$ & 120 & 130 & 145 & 160 \\
\hline Depression before the induced draft fan, $\mathrm{kgf} / \mathrm{m}^{2}$ & 260 & 270 & 285 & 300 \\
\hline
\end{tabular}

The analysis of the mode parameters obtained for natural gas fired TGMP-314 boiler in increased load modes revealed an increase in the gas flow rate from 80.6 to $86.7 \mathrm{~m}^{3} /$ t, which should be considered when assessing the boiler 
efficiency at increased loads. Besides, the increase in NOx emission levels should be noted, as it may have an adverse impact on the environmental parameters of the power plant. However, the obtained results pointing to $\mathrm{NO}_{\mathrm{x}}$ level increase cannot be regarded final, as there is a significant number of technological and mode methods of reducing harmful emissions into the atmosphere. One of the practicable methods providing for the reduction of $\mathrm{NO}_{\mathrm{x}}$ levels by 30-40\% on TGMP-314 boilers consists in combining the principle of increasing the single burner capacity with organizing the graded (compartmented) distribution and combustion of gas. Implementation of such solutions raises the possibility of reliable operation of the boiler in a boost mode with a flame extended heightwise of the furnace and lower temperatures in the zone of maximum heat liberation, which will bring about the reduced intensity of formation of corrosive gas components, reduced $\mathrm{NO}_{\mathrm{x}}$ levels and corrosion rate, while preserving the design reliability parameters. It should be noted that the measures aimed at reducing the harmful emissions along with implementing increased load modes of the boiler, is a challenging and complex task, the solution of which requires additional studies.

\section{Conclusion}

Therefore, to switch TPP operating power-generating units into increased load modes it is important to reveal all the reserves and eliminate the factors restricting the load increase possibilities. The necessary conditions include ensuring the standard-compliant technical state of the main and auxiliary equipment, quality repairs, high general technical level and culture of equipment operation, implementation of relatively low-cost measures of enhancement and modernization of specific units and mechanisms. The obtained mode parameters of the TGMP-314 gas-fired boiler operation suggest that operation at increased loads is feasible and can be recommended as a method of raising the capacity of operating power-generating units provided that the measures aimed at reducing harmful emissions into the atmosphere are implemented.

\section{References}

[1] Mamonova, A.O., Khusnutdinova, E.M., and Khusnutdinov, A.N. (2020) Quality management when operating the power equipment. IOP Conf. Ser.: Mater. Sci. Eng., Kazan, 4-6 December 2019, 012039. doi:10.1088/1757-899X/915/1/012039.

[2] Pronobis, M. (2020) Chapter 3 - Modernization to reduce the flue gas loss. In: Pronobis, M., Ed., Environmentally Oriented Modernization of Power Boilers, Elsevier, 15-78. https://doi.org/10.1016/B978-0-12-819921-3.00003-0.

[3] Kalina, J. (2014) Equipment sizing in a coal-fired municipal heating plant modernisation project with support for renewable energy and cogeneration technologies. Energy Conversion and Management, 86, 1050-1058. https://doi.org/10.1016/j.enconman.2014.06.079.

[4] Ostrowski, P., Szelejewski, F., Zymelka, P. (2020) Assessment of improvement in the energy and exergy efficiency of the gas heat plant after the exhaust gas cooled down below the dew point and the use of recovered heat. Energy, 190, 116179. https://doi.org/10.1016/j.energy.2019.116179.

[5] Sarkis, J., Cordeiro, J.J. (2012) Ecological modernization in the electrical utility industry: An application of a bads-goods DEA model of ecological and technical efficiency. European Journal of Operational Research, $219 \quad$ (2), $386-395$. https://doi.org/10.1016/j.ejor.2011.09.033.

[6] Fu, W., Wang, L., Yang, Y. (2021) Optimal design for double reheat coal-fired power plants with post-combustion $\mathrm{CO}_{2}$ capture: A novel thermal system integration with a carbon capture turbine. Energy, 221, 119838, https://doi.org/10.1016/j.energy.2021.119838.

[7] Zhang, K., Zhao, Y., Liu, M., Gao, L., Fu, Y., Yan, J. (2021) Flexibility enhancement versus thermal efficiency of coal-fired power units during the condensate throttling processes. Energy, 218, 119534. https://doi.org/10.1016/j.energy.2020.119534.

[8] Cao, R., Lu, Y., Yu, D., Guo, Y., Bao, W., Zhang, Z., Yang, C. (2020) A novel approach to improving load flexibility of coal-fired power plant by integrating high temperature thermal energy storage through additional thermodynamic cycle. Applied Thermal Engineering, 173, 115225. https://doi.org/10.1016/j.applthermaleng.2020.115225.

[9] Wang, D., Li, H., Wang, C., Zhou, Y., Li, X., Yang, M. (2021) Thermodynamic analysis of coal-fired power plant based on the feedwater heater drainage-air preheating system. Applied Thermal Engineering, 185, 116420. https://doi.org/10.1016/j.applthermaleng.2020.116420.

[10] Alsanousie, A.A., Elsamni, O.A., Attia, A.E., Elhelw, M. (2021) Transient and troubleshoots management of aged small-scale steam power plants using Aspen Plus Dynamics. Energy, 223, 120079. https://doi.org/10.1016/j.energy.2021.120079. 


\title{
Переведення енергоблоків потужністю 300 МВт з газомазутними котлами на роботу при підвищеному навантаженні
}

\author{
Степан Мисак, Марта Кузнецова, Марта Мартиняк-Андрушко \\ Наиіональний університет "Львівська політехніка", вул. Степана Бандери, 12, м. Львів, 79013, Украӥна
}

\begin{abstract}
Анотація
Основною метою даної роботи $є$ розроблення рекомендацій $з$ переведення діючих енергоблоків потужністю 300 МВт на роботу при підвищеному навантаженні шляхом використання прийнятих у розрахунках і при виготовленні енергетичного обладнання резервів зі збереженням критеріїв надійності $\mathrm{i}$ показників економічності його роботи. Підвищення потужності діючих енергоблоків відбувається у три етапи. На першому етапі проводиться обстеження технічного стану і умов експлуатації, визначення заходів, спрямованих на підвищення потужності, перевантажувальних можливостей, причин, що їх обмежують, заходів 3 модернізації і покращення технічного стану існуючого обладнання. Другий етап включає розроблення технічних рішень і реконструктивних заходів для збільшення пропускної здатності систем. На третьому етапі проводяться дослідження і випробування обладнання енергоблоків в широкому діапазоні навантажень, включаючи режими перевантажень, з оцінкою і порівнянням критеріїв надійності і показників економічності. Технічні заходи з удосконалення і модернізації обладнання $є$ малозатратними. Більшість із них зводиться до забезпечення нормального технічного стану існуючого основного і допоміжного обладнання енергоблоків.
\end{abstract}

Ключові слова: енергоблок; котел; підвищення навантаження; модернізація; реконструкція. 